\title{
PENGARUH PENERAPAN ISO 9001:2008, MOTIVASI, KEMAMPUAN, DAN LINGKUNGAN KERJA TERHADAP KINERJA KARYAWAN PUSKESMAS SURABAYA DENGAN EMPLOYEE ENGAGEMENT SEBAGAI VARIABEL MODERATING
}

\author{
Mega Arisia Dewi \\ megaarisiadewi@stiesia.ac.id \\ Sekolah Tinggi Ilmu Ekonomi Indonesia (STIESIA) Surabaya
}

\begin{abstract}
Abstrak
Penelitian ini bertujuan untuk menguji apakah ISO 9001:2008, motivasi kerja, kemampuan kerja, employee engagement dan lingkungan kerja berpengaruh terhadap kinerja karyawan serta untuk menguji apakah Employee Engagement memoderasi ISO 9001:2008, motivasi kerja, kemampuan kerja, dan lingkungan kerja terhadap kinerja karyawan. Populasi dalam penelitian ini adalah karyawan yang bekerja pada puskesmas yang bersertifikat ISO 9001:2008 di Surabaya yang terdiri dari karyawan bagian upaya kesehatan masyarakat, karyawan bagian upaya kesehatan perorangan, karyawan Tata Usaha. Penelitian menggunakan purposive sampling dalam pengambilan sampel. Teknik analisa data menggunakan metode Analisis Data Multivariate. Hasil penelitian menunjukkan bahwa ISO 9001:2008, motivasi kerja, kemampuan kerja, employee engagement dan lingkungan kerja berpengaruh secara signifikan terhadap kinerja karyawan. Hal ini menunjukkan bahwa Puskesmas sudah memiliki standar sistem operasional yang jelas dapat membantu karyawan bekerja dengan output mutu yang baik dan Puskesmas sudah memiliki kebijakan mutu, sasaran mutu, dan strategi dalam mencapai sasaran mutu. Selain itu, employee engagement mampu memoderasi pengaruh ISO 9001:2008, motivasi kerja, kemampuan kerja, dan lingkungan kerja terhadap kinerja karyawan. Hal ini mengindikasikan bahwa peran serta dan antusiasme karyawan untuk bekerja dengan rasa keterikatan emosional yang positif dan ditunjang dengan adanya kebijakan mutu, sasaran mutu dan strategi dalam mencapai sasaran mutu dari pukesmas dapat meningkatkan kinerja karyawan.
\end{abstract}

Kata kunci: ISO 9001:2008, Motivasi, Kemampuan, Lingkungan Kerja, Employee Engagement

\section{Pendahuluan}

Pembangunan

diselenggarakan dalam upaya untuk meningkatkan kesadaran, kemauan dan kemampuan hidup sehat bagi setiap orang agar terwujud derajat kesehatan masyarakat yang optimal. Untuk mencapai tujuan pembangunan kesehatan tersebut, maka diselenggarakan berbagai upaya kesehatan secara menyeluruh, berjenjang dan terpadu. Puskesmas sebagai pusat pelayanan kesehatan strata pertama yang menyelenggarakan kegiatan pelayanan kesehatan secara menyeluruh dan berkesinambungan harus menyediakan sumber daya manusia yang berkualitas. Sumber daya manusia itu sendiri memegang peranan sangat penting dalam operasional suatu organisasi. Karyawan sebagai individu dalam organisasi merupakan bagian dari struktur organisasi yang memiliki peranan besar dalam menentukan tercapainya tujuan organisasi.

Berbagai cara dilakukan puskesmas untuk mempertahankan talenta terbaiknya agar bertahan dan menciptakan efektivitas serta kinerja optimal dalam sebuah organisasi. Salah satu caranya dengan menerapkan ISO 9001:2008. ISO 9001:2008 merupakan standar internasional untuk sistem manajemen mutu atau kualitas yang didalamnya menetapkan persyaratan-persyaratan dan 
rekomendasi untuk desain dan penilaian dari suatu sistem manajemen mutu.

Selain ISO 9001:2008, terdapat faktor lain yang mempengaruhi kinerja, salah satu faktornya adalah lingkungan kerja. Lingkungan kerja merupakan segala sesuatu di sekitar pekerja dan dapat berpengaruh terhadap pekerjanya. Sukmawati (2008) menyatakan bahwa lingkungan kerja lebih dititikberatkan pada keadaan fisik tempat kerja seperti temperatur ruangan yang tepat, jauh dari suara yang bising, penerangan di tempat kerja dan sebagainya, sehingga mempunyai pengaruh terhadap kinerja karyawan yang akhirnya berpengaruh terhadap produktivitas kinerja karyawan. Lingkungan yang baik akan meningkatkan kerja, begitu pula sebaliknya apabila lingkungan kerja kurang tenang, akan dapat mempertinggi tingkat kesalahan yang mereka lakukan. Hafizurrahman (2011), dalam penelitiannya menyebutkan bahwa salah satu faktor yang mempengaruhi kinerja adalah lingkungan kerja dimana Kemampuan karyawan dan keadaan lingkungan kehidupan yang kondusif terutama ketersediaan tempat kerja atau suasana kerja yang menyenangkan, aturan yang lebih jelas dan melindungi perawat akan lebih meningkatkan kinerja.

Selain itu, motivasi kerja dan kemampuan merupakan faktor yang mempengaruhi kinerja karyawan. Motivasi kerja sebagai motor penggerak yang paling vital dalam sebuah pencapaian kinerja. Tanpa motivasi, pegawai tidak akan berhasil untuk menyelesaikan sebuah pekerjaan secara maksimal karena tidak ada kemauan yang berasal dari dalam diri karyawan itu sendiri, yang muncul hanyalah rutinitas (Sutrischastini dan Riyanto, 2015). Kemampuan kerja berpengaruh signifikan terhadap kinerja karyawan. Semakin baik kemampuan yang dimiliki karyawan maka kinerja yang dihasilkan juga semakin baik. Karyawan yang memiliki kemampuan akan lebih mudah mencapai kinerja maksimal Permatasari et al. (2016). Rahmayanti (2014) meneliti pengaruh motivasi kerja terhadap kinerja karyawan. Hasil penelitian menunjukkan bahwa motivasi kerja berpengaruh secara signifikan terhadap kinerja karyawan. Nilai koefisien dan determinasi $\left(R^{2}\right)$ sebesar $40,96 \%$ yang menunjukkan bahwa motivasi kerja mempengaruhi kinerja karyawan sebesar 40,96\%.

Faktor lain yang mempengaruhi kinerja karyawan puskesmas adalah employee engagement, yang mana mampu bersinergi dalam menciptakan pelayanan kesehatan yang maksimal bagi masyarakat. Konsep employee engagement memiliki implikasi yang lebih jauh dan engagement dinilai lebih penting daripada kepuasan saja, yang mana dapat memberikan informasi mengenai tingkat keterikatan karyawan terhadap faktor organisasi. Faktor ini mendorong karyawan untuk melakukan usaha yang maksimal melebihi yang diharapkan.

Karyawan diharapkan mempunyai engagement, suatu keterlibatan, komitmen, keinginan untuk berkontribusi dan rasa memiliki (ownership) terhadap pekerjaan dan organisasi. Di dalam terminologi ini, termasuk pula di dalamnya timbulnya rasa saling percaya (trust), loyalitas terhadap pekerjaan dan perusahaan, serta kebanggaan terhadap organisasi dan semangat bekerjasama. Kondisi-kondisi tersebut yang kemudian melahirkan istilah Employee Engagement. Konsep employee engagement menjadi penting dalam mengkonsepsualiasikan dan menentukan peranan modal manusia terhadap kinerja organisasi.

Penelitian ini bertujuan untuk menguji apakah ISO 9001:2008, Motivasi, Kemampuan, Lingkungan Kerja dan Employee Engagement berpengaruh positif terhadap kinerja karyawan serta menguji apakah Employee engagement memoderasi penerapan ISO 9001:2008 lingkungan kerja terhadap kinerja karyawan.

Penelitian ini, diharapkan dapat memberikan manfaat diantaranya sebagai sumbangan pemikiran empiris mengenai employee engagement dan lingkungan kerja terhadap pengaruh penerapan ISO 9001:2008 guna diterapkan dan dikembangkan di puskesmas, sebagai bahan pertimbangan untuk meningkatkan sistem manajemen mutu ISO 9001:2008 
dan mengambil keputusan untuk meningkatkan kinerja karyawan Puskesmas di Surabaya dan sebagai bahan pertimbangan bagi Puskesmas di Surabaya, tentang faktor-faktor yang mempengaruhi kinerja karyawan.

\section{TINJAUAN TEORETIS}

\section{International Organization Standardization (ISO) 9001:2008}

for

ISO 9001:2008 adalah suatu standar internasional untuk sistem manajemen mutu kualitas yang menetapkan persyaratan-persyaratan dan rekomendasi untuk desain penilaian dari suatu manajemen mutu. ISO 9001:2008 hanya menyempurnakan dan memodifikasi persyaratan yang telah ada dalam ISO 9001:2000. Sistem manajemen mutu ini untuk memenuhi kepuasan pelanggan/pasien (customers satisfaction) dan peningkatan yang berkesinambungan (continuous processes improvement) Heuvel (2005).

Zuhrawaty (2009) menjelaskan bahwa prinsip - prinsip manajemen mutu terdiri dari delapan bagian, yaitu : (1) Fokus Pada Pelanggan (Customer Focus); (2) Kepemimpinan (Leadership); Keterlibatan Karyawan (Involvement of people); (4) Pendekatan Proses (Process approach); (5) Pendekatan Sistem Untuk Pengelolaan (System approach to management); (6) Peningkatan Berkelanjutan (Continual improvement); (7) Pendekatan Faktual pada Pengambilan Keputusan (Factual approach to decision making); dan (8) Hubungan yang Saling Menguntungkan dengan Pemasok (Mutually beneficial supplier relationships).

\section{Teori Attribusi}

Menurut As'ad (2003), teori atribusi (Attribution Theory) pertama kali dikemukakan oleh Heider (1958). Heider mengatakan bahwa pada dasarnya orang selalu termotivasi untuk memahami perilaku orang lain dalam interaksi sosial. Menurut Dayakisni dan Hudaniah (2006) atribusi merupakan proses dilakukan untuk mencari sebuah jawaban atau pertanyaan mengapa atau apa sebabnya, atas perilaku orang lain ataupun diri sendiri.

Pendekatan teori atribusi mengenai kinerja dirumuskan $P=f(M \times A)$. Di mana $P$ adalah performance, $M$ adalah motivation, A adalah ability. Dengan berpedoman pada formula teori atribusi ini, maka kinerja merupakan hasil interaksi antara motivasi dengan kemampuan dasar. Jadi dapat disimpulkan bahwa seseorang dengan motivasi yang tinggi tetapi memiliki kemampuan yang rendah akan memberikan hasil kerja yang rendah. Demikian sebaliknya, seseorang dengan kemampuan yang tinggi namun memiliki motivasi yang rendah juga akan menghasilkan kinerja yang rendah. Sehingga dibutuhkan keseimbangan antara motivasi dengan kemampuan.

Memotivasi karyawan bertujuan untuk memperluas keterampilan dalam memenuhi tuntutan organisasi. Setiap manajer harus memiliki tanggung jawab untuk bekerja dengan karyawan, mengetahui kebutuhan masing-masing dan menempatkan mereka berdampingan dengan kebutuhan organisasi (Hanafi dan Yohana, 2017).

Menurut Mangkunegara (2007), teori motivasi dapat dikategorikan menjadi tiga kelompok, yaitu:

1. Teori motivasi dengan pendekatan isi, menekankan pada faktor-faktor yang membuat karyawan melakukan suatu tindakan tertentu. Seorang bekerja karena dorongan untuk memenuhi kebutuhan yang bermacam-macam. Apabila karyawan tidak dapat memenuhi kebutuhannya dengan bekerja pada suatu perusahaan, maka karyawan tersebut akan menunjukkan perilaku kecewa. Kekecewaan tersebut dapat mengakibatkan penurunan kinerja karyawan.

2. Teori motivasi dengan pendekatan penguat, menekankan pada faktorfaktor yang dapat meningkatkan suatu tindakan dilakukan atau yang dapat mengurangi suatu tindakan.

3. Teori motivasi dengan pendekatan proses, tidak hanya menekankan pada faktor apa yang membuat karyawan bertindak, tetapi bagaimana karyawan termotivasi. Misalnya motivasi 
berprestasi, yang diartikan sebagai sesuatu yang mendorong diri seseorang untuk mengerjakan atau melaksanakan suatu kegiatan atau tanggungjawab secara maksimal untuk mencapai prestasi kerja yang tinggi.

Kemampuan (ability) menunjukkan suatu kapasitas individu untuk mengerjakan berbagai tugas dalam suatu pekerjaan (Robbins et al., 2015). Sehingga dapat dijelaskan bahwa untuk melakukan suatu pekerjaan dibutuhkan kemampuan untuk mendukung dalam melaksanakan pekerjaan yang diberikan oleh perusahaan. Kemampuan individu pada dasarnya terdiri dari 2 faktor yaitu kemampuan intelektual dan kemampuan fisik. Kemampuan intelektual adalah kemampuan yang dibutuhkan untuk menjalankan kegiatan mental. Sedangkan kemampuan fisik adalah kemampuan yang dibutuhkan untuk melakukan pekerjaan yang menuntut adanya stamina, kecekatan, kekuatan, dan keterampilan. Permatasari et al., (2016) menyatakan bahwa kemampuan kerja memiliki pengaruh yang signifikan terhadap kinerja karyawan. Berarti karyawan setuju bahwa karyawan yang dapat memahami pekerjaan yang diberikan, maka karyawan tersebut dapat mengatasi hambatan dalam pekerjaan. Kemampuan kerja dapat berupa daya ingat yang tinggi, kemampuan berhitung yang tinggi, karyawan yang cepat tanggap dalam melaksanakan pekerjaan, karyawan yang mampu bekerja melebihi jam kerja.

\section{Lingkungan Kerja}

Faktor lain yang mempengaruhi kinerja selain penerapan ISO 9001:2008 adalah lingkungan kerja. Menurut Nitisemito (2002) lingkungan kerja yaitu segala sesuatu yang ada di sekitar pekerja, yang dapat mempengaruhi dirinya dalam menjalankan tugas. Dalam lingkungan kerja, setiap karyawan dituntut untuk dapat melaksanakan pekerjaan sesuai dengan jabatan yang dipegang dan dapat berinteraksi dengan lingkungan serta rekan kerja yang memiliki karakter yang berbeda-beda.

Dhermawan et al. (2012) dalam artikelnya menyebutkan bahwa ada beberapa faktor yang mempengaruhi pembentukan perilaku yang berhubungan dengan kondisi lingkungan kerja yang dibedakan menjadi dua macam, yaitu lingkungan kerja fisik dan lingkungan kerja non fisik. Kondisi lingkungan kerja yang nyaman akan mempengaruhi karyawan bekerja lebih giat dan konsentrasi menyelesaikan tugas-tugasnya sesuai jadwal.

Schultz dan Sydney (2015) menjelaskan lingkungan kerja fisik merupakan salah satu faktor yang mempengaruhi kinerja karyawan. Seorang karyawan yang bekerja di lingkungan kerja fisik yang baik dan mendukung untuk bekerja secara optimal akan menghasilkan kinerja yang baik pula, sebaliknya apabila seorang karyawan bekerja di lingkungan kerja fisik yang tidak mendukung atau kurang memadai untuk bekerja secara optimal maka akan membuat karyawan menjadi tidak nyaman, cepat lelah, malas sehingga kinerja karyawan tersebut akan rendah.

\section{Kinerja}

Menurut Mangkunegara (2007) istilah kinerja berasal dari kata job performance atau actual performance (prestasi kerja atau prestasi sesungguhnya yang dicapai oleh seseorang). Jadi, kinerja (prestasi kerja) adalah hasil kerja baik secara kualitas maupun kuantitas yang dicapai oleh seseorang dalam melaksanakan tugas sesuai tanggung jawab yang diberikan. Mangkunegara (2007) juga menjelaskan faktor-faktor yang mempengaruhi pencapaian kinerja, yaitu:

1. Faktor kemampuan (ability)

Secara psikologis, kemampuan (ability) pegawai terdiri dari kemampuan potensi (IQ) dan kemampuan reality (knowledge dan skil). Artinya, pegawai yang memiliki IQ di atas rata-rata (IQ 110 - 120) dengan pendidikan yang memadai untuk jabatannya dan terampil dalam mengerjakan pekerjaan sehari-hari maka ia akan lebih mudah mencapai kinerja yang diharapkan. Oleh karena itu, pegawai perlu ditempatkan pada pekerjaan yang sesuai dengan keahliannya.

2. Faktor motivasi 
Motivasi terbentuk dari sikap (attitude) seorang pegawai dalam menghadapi situasi kerja. Motivasi merupakan kondisi yang menggerakkan diri pegawai yang terarah untuk mencapai tujuan organisasi (tujuan kerja).

Maka dapat disimpulkan bahwa kinerja atau performance adalah hasil kerja yang dapat dicapai seseorang atau kelompok orang dalam suatu perusahaan sesuai dengan wewenang dan tanggung jawab masing-masing dalam upaya pencapaian tujuan perusahaan secara legal, tidak melanggar hukum, tidak bertentangan dengan etika dan dipengaruhi oleh kemampuan, keinginan, lingkungan, kesempatan. Arini et al., (2015) meneliti tentang pengaruh motivasi dan kemampuan terhadap kinerja karyawan. Hasil penelitian menunjukkan bahwa kemampuan kerja dan motivasi kerja berpengaruh terhadap kinerja karyawan sebesar $30,7 \%$, sedangkan $69,3 \%$ dipengaruhi oleh variabel lain.

\section{Employee Engagement}

Employee Engagement merupakan gagasan dalam perilaku organisasi yang menjadi daya tarik dalam beberapa tahun terakhir. Daya tarik ini timbul karena employee engagement berpengaruh pada kinerja organisasi secara keseluruhan. Istilah employee engagement diperkenalkan oleh kelompok Gallup pada tahun 2004. Gallup mendefinisikannya sebagai peran serta dan antusiasme untuk bekerja. Gallup juga mengkaitkan employee engagement dengan rasa keterikatan emosional yang positif dan komitmen karyawan dalam Dernovsek (2008).

Dikutip oleh Saks (2006), bahwa salah satu faktor yang dapat meningkatkan engagement adalah dengan meningkatkan penilaian karyawan terhadap dukungan organisasi yang mereka terima (perceived organizational support). Karyawan yang memiliki keterikatan dengan perusahaan akan berkomitmen secara emosional dan intelektual terhadap perusahaan serta akan memberikan usaha terbaiknya melebihi apa yang dijadikan target dalam suatu pekerjaan.
Untuk mendapatkan komitmen karyawan, organisasi berusaha untuk meningkatkan kepuasan karyawan dengan memperhatikan kesejahteraannya. Dengan demikian, yang menjadi tugas organisasi adalah mampu memotivasi dan menunjukkan sejauh mana dukungan perusahaan terhadap karyawan sehingga karyawan akan memberi penilaian positif bagi organisasi. Berbagai penelitian telah menunjukkan bahwa karyawan yang puas terhadap organisasinya cenderung akan menunjukkan komitmen yang lebih tinggi (Moynihan et al., 2000; Warsi et al., 2009; Asikgil, 2011; Samad, 2011).

Gallup (2004) mengelompokkan karyawan dalam 3 kategori berdasarkan tingkat engagement yaitu:

a. Karyawan yang 'terikat' (engaged employees), mereka bekerja dengan bersemangat dan merasakan hubungan yang dalam dengan perusahaan mereka. Mereka umumnya menjadi bagian dari lahirnya ide-ide inovatif yang memajukan perusahaan.

b. Karyawan yang 'Tidak Terikat' (notengaged employees): secara praktis mereka tidak lagi memikirkan kemajuan perusahaan. Mereka seperti orang yang tidur sambil berjalan. Mereka melewatkan waktu mereka untuk bekerja, tetapi tidak cukup memberikan energi atau semangat dalam pekerjaannya.

c. Karyawan yang 'Lepas' (actively disengaged employees): mereka bukan hanya tidak puas dengan tempat kerjanya, mereka bahkan secara terbuka menampakkan ketidakpuasannya di tempat kerja. Setiap hari mereka seolah menumpang atau bahkan menggerogoti apa yang dihasilkan oleh rekan-rekan kerjanya.

\section{Penelitian Terdahulu}

Beberapa penelitian terdahulu yang terkait dengan faktor-faktor yang mempengaruhi kinerja karyawan antara lain sebagai berikut:

Semuel dan Zulkarnain (2011) meneliti tentang pengaruh sistem manajemen mutu ISO terhadap kinerja karyawan melalui budaya kualitas perusahaan (studi kasus PT.Otsuka 
Malang). Penelitian menyimpulkan bahwa komitmen perusahaan dalam menjalankan sistem manajemen mutu ISO 9001 memiliki pengaruh langsung terhadap kinerja karyawan. Budaya kualitas memiliki persepsi yang baik, namun untuk dua indikator pembentuknya, yaitu empowerement dan involvement, serta quality improvement teamwork masih memiliki persepsi yang rendah dari karyawan. Penerapan SMM ISO 9001 mampu meningkatkan kinerja karyawan secara signifikan melalui budaya kualitas perusahaan sebagai mediasinya.

Antariksa et al. (2014) meneliti tentang pengaruh penerapan SMM ISO 9001:2008 terhadap kinerja balanced scorecard. Hasil penelitian menunjukkan bahwa penerapan SMM ISO di Perguruan Tinggi, khususnya Universitas Brawijaya, memberikan pengaruh positif terhadap kinerja untuk 4 perspektif dalam balanced scorecard yaitu perspektif pelanggan, perspektif keuangan, perspektif bisnis internal, dan perspektif pembelajaran dan pertumbuhan.

Sutrischastini dan Riyanto (2015) meneliti tentang pengaruh motivasi kerja terhadap kinerja pegawai. Sampel yang diambil sebanyak 162 responden yang bekerja di kantor sekretariat Kabupaten Gunung Kidul. Variabel motivasi diukur dengan menggunakan variabel insentif, motif, dan harapan. Hasil penelitian menunjukkan bahwa variabel motivasi kerja yang diukur dengan menggunakan indikator insentif, motif, dan harapan berpengaruh positif dan signifikan terhadap kinerja pegawai kantor sekretariat di Kabupaten Gunung Kidul.

Sidanti (2015) meneliti tentang pengaruh lingkungan kerja, disiplin kerja, dan motivasi kerja terhadap kinerja pegawai negeri sipil. Hasil penelitian menunjukkan bahwa variabel disiplin kerja dan motivasi kerja berpengaruh positif signifikan terhadap kinerja pegawai negeri sipil. Varibel lingkungan kerja tidak berpengaruh signifikan terhadap negeri sipil di sekretariat DPRD Kabupaten Madiun.

Hanafi dan Yohana (2017) melakukan penelitian tentang pengaruh motivasi dan lingkungan kerja terhadap kinerja karyawan dengan kepuasan kerja sebagai variabel mediasi. Hasil penelitian menunjukkan bahwa motivasi yang dimediasi dengan kepuasan kerja berpengaruh signifikan terhadap kinerja karyawan. Untuk variabel lingkungan kerja yang dimediasi oleh kepuasan kerja memiliki pengaruh signifikan terhadap kinerja karyawan.

\section{Pengaruh Sistem Manajemen Mutu ISO 9001:2008 terhadap Kinerja Karyawan Puskesmas di Surabaya}

Puskesmas di Kota Surabaya sudah mampu melaksanakan standar pelayanan kesehatan pada masyarakat secara konsisten. Hal ini ditunjukkan dengan pelayanan yang diberikan oleh puskesmas tersebut kepada masyarakat sangat luar biasa dan sudah sesuai dengan harapan masyarakat. Adanya sertifikasi ISO ini diharapkan, terdapat komitmen standar kinerja yang baik sehingga dapat meningkatkan kualitas pelayanan khususnya pelayanan publik seperti yang diharapkan seluruh lapisan masyarakat. Pembangunan kesehatan tidak mungkin berhasil tanpa dukungan, peran serta dan komitmen seluruh pemangku kepentingan dan seluruh lapisan masyarakat.

Sistem manajemen mutu adalah sistem manajemen yang mengangkat kualitas sebagai strategi usaha dan berorentasi pada kepuasan pelanggan dengan melibatkan seluruh anggota organisasi. Pada sistem manajemen kualitas ISO 9001:2008 ini mengharuskan organisasi untuk menetapkan rencanarencana dan menerapkan proses-proses pengukuran, pemantauan, analisis, dan peningkatan yang diperlukan agar menjamin kesesuaian dari produk, menjamin kesesuaian dari sistem manajemen kualitas, dan meningkatkan terus-menerus efektifitas dari sistem manajemen kualitas.

Hernandez (2010) mengatakan bahwa ISO 9001 (International Orgnization for Standarization) merupakan satu set kebijakan umum yang didokumentasikan untuk menjelaskan sistem dan proses serta tugas lintas fungsional. Begitupun dengan ISO 9001:2008 yang merupakan bagian dari ISO 9001. ISO 9001:2008 
mendokumentasikan proses dari sistem manajemen mutu, salah satunya dengan melakukan pemetaan terhadap proses dan peninjauan ulang terhadap tanggung jawab dari stakeholder untuk menilai kinerja.

Cohen (2007) mengatakan bahwa employee engagement adalah suatu keterlibatan, komitmen, keinginan untuk berkontribusi dan rasa memiliki terhadap pekerjaan dan organisasi. Dalam prinsip ISO 9001:008 nomor 4 dijelaskan bahwa karyawan pada semua tingkatan merupakan unsur dari suatu organisasi. Keterlibatan mereka senantiasa memberikan sumbangan bagi kepentingan perusahaan. Sehingga untuk menerapkan ISO 9001:2008 diperlukan keterlibatan karyawan yang menjadi unsur terciptanya employee engagement di dalam perusahaan. Robinson et al. (2004) menyatakan employee engagement sebagai sikap positif yang dimiliki karyawan terhadap organisasi dia bekerja dan nilai-nilai yang ada di dalam organisasi tersebut. Karyawan yang memiliki rasa engage terhadap perusahaan cenderung akan meningkatkan kinerjanya.

H1: Penerapan Sistem Manajemen Mutu ISO 9001: 2008 berpengaruh positif terhadap kinerja karyawan

$\mathrm{H} 2$ : Employee engagement memoderasi Sistem Manajemen Mutu ISO 9001:2008 terhadap kinerja karyawan

\section{Pengaruh Motivasi dan Kemampuan Kerja terhadap Kinerja Karyawan Puskesmas di Surabaya}

Teori atribusi (Attribution Theory) mengemukakan bahwa pada dasarnya orang selalu termotivasi untuk memahami perilaku orang lain dalam interaksi sosial. Menurut Dayakisni dan Hudaniah (2006) atribusi merupakan proses dilakukan untuk mencari sebuah jawaban atau pertanyaan mengapa atau apa sebabnya, atas perilaku orang lain ataupun diri sendiri.

Pendekatan teori atribusi mengenai kinerja dirumuskan $P=f(M \times A)$. Di mana $P$ adalah performance, $M$ adalah motivation, A adalah ability. Dengan berpedoman pada formula teori atribusi ini, maka kinerja merupakan hasil interaksi antara motivasi dengan kemampuan dasar. Hasil penelitian Anggraeni (2011) menunjukkan bahwa kemampuan dan motivasi berpengaruh positif dan signifikan terhadap kinerja pegawai. Variabel kemampuan dan motivasi mempengaruhi kinerja pegawai sebesar $86 \%$.

$\mathrm{H}_{3}$ : Motivasi dan kemampuan kerja berpengaruh positif terhadap kinerja karyawan
$\mathrm{H}_{4}$ : Employee engagement memoderasi motivasi dan kemampuan kerja terhadap kinerja karyawan

\section{Pengaruh Employee Engagement terhadap Kinerja Karyawan Puskesmas di Surabaya}

Menumbuhkan rasa employee engagement di dalam organisasi dapat dilakukan dengan cara berusaha menerapkan pola kepimpinan yang suportif, yang dituntun dengan visi yang jernih dan nilai organisasi yang kuat. Peningkatan kerja juga dipengaruhi oleh karakteristik lingkungan pekerjaan seseorang. Orang bekerja mempunyai makna untuk mengisi waktu luang, bersosialisasi, memanfaatkan ilmunya, dan seseorang yang menyenangi pekerjaanya akan tampak lebih giat dan semangat dalam bekerja dan menyelesaikan tugas-tugas yang diberikan kepadanya.

Development Dimensions International, Inc (2006) menjelaskan bahwa tingkat Employee Engagement dan kinerja karyawan menunjukkan ketika skor engagement tinggi, karyawan akan lebih puas terhadap pekerjaannya, tingkat keinginan untuk memninggalkan pekerjaan menjadi rendah dan karyawan menjadi lebih produktif. Berarti employee engagement memberikan hasil yang positif terhadap perilaku karyawan. Hasil dari penelitian ini memperlihatkan pengaruh signifikan antara employee engagement dan kinerja karyawan dan pada akhirnya juga memberikan dampak positif di level organisasi yaitu pertumbuhan dan produktivitas organisasi. Sebaik apapun strategi yang ditetapkan pihak manajemen tidak akan ada gunanya 
bila tidak diamini oleh seluruh karyawan yang ada di organisasi. Oleh karena itu, peran aktif dari karyawan sangat dibutuhkan untuk keberhasilan implementasi ISO 9001:2008.

Beberapa hal yang dapat dilakukan untuk keberhasilan implementasi ISO 9001:2008 antara lain : Setiap karyawan harus memahami pentingnya kontribusi dan peran mereka dalam organisasi, setiap karyawan harus mengidentifikasi hambatan terhadap kinerja mereka, setiap karyawan harus memahami tugas dan tanggung jawab mereka, setiap karyawan harus secara aktif mencari kesempatan untuk meningkatkan kompetensi, pengetahuan dan pengalaman, dan setiap karyawan bebas berbagi pengetahuan dan pengalaman.

\section{$\mathrm{H}_{5}$ : Penerapan Employee Engagement berpengaruh positif terhadap kinerja karyawan}

\section{Pengaruh Lingkungan Kerja terhadap Kinerja Karyawan Puskesmas di Surabaya}

Di samping itu, organisasi yang menerapkan ISO 9001:2008 juga perlu mengelola sumber daya organisasi. Dalam hal ini, kewajiban organisasi adalah menyediakan dan memelihara infrastruktur kerja yang diperlukan. Menurut Djojowirono (2005:24), infrastruktur kerja adalah alat yang diperlukan untuk menggerakkan kegiatan manajemen dalam rangka mencapai tujuan organisasi. Adanya fasilitas kerja yang disediakan oleh organisasi akan memudahkan pegawai dalam melaksanakan pekerjaan, sehingga dapat meningkatkan produktivitas kerja.

Colquit et al. dalam Saks (2006) menjelaskan beberapa kondisi lingkungan kerja yang baik yang diharapkan dapat menciptakan employee engagement. Lingkungan kerja yang diharapkan berkeadilan akan membangun ikatan emosi yang lebih baik pada organisasi. Didalam lingkungan kerja yang baik akan memberikan kenyamanan pribadi dan dapat membangkitkan semangat kerja karyawan sehingga dapat mengerjakan tugas-tugasnya dengan baik. Disamping itu karyawan akan lebih senang dan nyaman dalam bekerja jika fasilitas yang ada dalam keadaan bersih, tidak bising, pertukaran udara yang cukup baik dan peralatan yang memadai serta relatif modern. Dengan lingkungan kerja yang baik akan berpengaruh terhadap kepuasan kerja yang dirasakan oleh karyawan.

Stoner dalam Sindoro (2002:419) menjelaskan bahwa kondisi lingkungan kerja juga sangat menentukan kinerja karyawan karena pada dasarnya karyawan itu bukan mesin yang tanpa hati, semakin tinggi kualitas seseorang maka akan semakin tinggi harapannya tentang kondisi lingkungan kerja yang baik. Keadaan lingkungan kerja yang cukup menentukan adanya kelancaran suatu pekerjaan. Apabila lingkungan kerja memungkinkan, maka para karyawan akan menjadikan tempat kerja merupakan sesuatu yang menyenangkan dalam melaksanakan aktivitas kerjanya, sehingga pada akhirnya akan dapat menimbulkan rasa keterikatan dan keterlibatan karyawan yang lebih pada pekerjaannya sehingga karyawan akan merasa puas dengan pekerjaannya.

Karyawan dapat melaksanakan aktivitasnya dengan baik, sehingga dicapai prestasi kinerja yang optimal, apabila didukung oleh sifat keinginan dan keterlibatan karyawan dan kondisi lingkungan kerja yang baik.

\section{$\mathrm{H}_{6}$ : Penerapan Lingkungan Kerja berpengaruh positif terhadap kinerja karyawan \\ $\mathrm{H}_{7}$ : Employee Engagement memoderasi Lingkungan Kerja terhadap kinerja karyawan}

\section{METODE PENELITIAN \\ Populasi dan Sampel}

Populasi penelitian ini menggunakan responden karyawan yang bekerja pada puskesmas yang bersertifikat ISO 9001:2008 di Surabaya. Teknik pengambilan sampel penelitian adalah purposive sampling. Purposive sampling merupakan teknik pengambilan sampel yang berdasarkan pada pertimbanganpertimbangan tertentu yang berdasarkan tujuan penelitian (Sekaran, 2006). Kriteria sampel yang diambil dalam penelitian adalah karyawan yang terlibat langsung 
dalam ruang lingkup penerapan sistem manajemen mutu ISO 9001:2008 di puskesmas bersertifikat ISO 9001:2008 seperti karyawan bagian UKM, UKP dan karyawan bagian TU dan memiliki status sebagai karyawan tetap. Adapun Puskesmas yang dijadikan tempat penelitian ada 7 (tujuh) antara lain Puskesmas Menur, Puskesmas Pucang Sewu, Puskesmas Ketabang, Puskesmas Makam Peneleh, Puskesmas Jagir, Puskesmas Ngaglik dan Puskesmas Kalirungkut. Dari semua kuesioner yang disebar peneliti, diperoleh 70 responden dari 7 (tujuh) puskesmas yang digunakan sebagai sampel penelitian. Responden dalam penelitian ini terdiri dari Kepala TU, Dokter / Bidan, Perawat, Pelaksana dan Administrasi.

Data penelitian ini adalah dalam bentuk persepsi responden yang dikumpulkan melalui penyebaran kuesioner dengan di antar langsung kepada responden. Skala pengukuran yang digunakan adalah pengukuran interval menggunaka skala likert dan skala rasio. Dimana dalam penelitian ini digunakan 5 skala likert yaitu 1 (sangat tidak setuju) hingga 5 (sangat setuju). Selain data primer, juga dibutuhkan data sekunder yaitu data tentang nama, alamat puskesmas yang memiliki sertifikat ISO 9001:2008.

\section{Definisi Operasional Variabel}

Penelitian ini menggunakan variabel dependen yaitu kinerja karyawan dengan variabel independen antara lain Sistem Manajemen Mutu ISO 9001:2008, Motivasi Kerja, Kemampuan Karyawan, Employee Engagement dan Karakteristik Lingkungan Kerja.

1. Variabel independen (Independent Variable)

a. Sistem Manajemen Mutu ISO 9001:2008 (ISO)

Sistem Manajemen Mutu ISO 9001:2008 adalah suatu standar internasional untuk sistem manajemen mutu kualitas yang menetapkan persyaratanpersyaratan dan rekomendasi untuk desain penilaian dari suatu manajemen mutu. ISO 9001:2008 hanya menyempurnakan dan memodifikasi persyaratan yang telah ada dalam ISO 9001:2000.

b. Motivasi Kerja (MOT)

As'ad (2003) mendefinisikan motivasi sebagai sesuatu yang menimbulkan semangat atau dorongan kerja. Oleh sebab itu, motivasi biasa disebut pendorong atau semangat kerja.

c. Kemampuan Karyawan (KEM) Kemampuan (ability) menunjukkan suatu kapasitas individu untuk mengerjakan berbagai tugas dalam suatu pekerjaan (Robbins et al., 2015). Sehingga dapat dijelaskan bahwa untuk melakukan suatu pekerjaan dibutuhkan kemampuan untuk mendukung dalam melaksanakan pekerjaan yang diberikan oleh perusahaan. Kemampuan individu pada dasarnya terdiri dari 2 faktor yaitu kemampuan intelektual dan kemampuan fisik.

d. Employee Engagement (EE)

Employee engagement sebagai sikap positif yang dimiliki karyawan terhadap organisasi tempat ia bekerja serta nilai-nilai yang dimiliki oleh organisasi tersebut.

e. Lingkungan Kerja (LK)

Lingkungan kerja adalah segala sesuatu yang ada di sekitar para pekerja yang dapat mempengaruhi dirinya dalam menjalankan tugastugas yang dibebankan.

\section{Variabel terikat (dependent variabe)}

Variabel terikat dalam penelitian ini adalah kinerja karyawan (KK) yaitu hasil kerja secara kualitas maupun kuantitas dari proses pekerjaan karyawan dalam melaksanakan pekerjaan meliputi kemampuan kerja, keandalan dan efektifitas kerja, pelayanan kepada pelanggan, kerjasama dan kualitas kerja.

\section{Teknik Analisis Data}

Data penelitian dianalisa dengan menggunakan metode Analisis Data Multivariate yang merupakan metode statistik deskriptif dan inferensial yang 
digunakan untuk menganalisis data lebih dari dua variabel penelitian.

Pengujian hipotesis dalam penelitian ini menggunakan regresi berganda (multiple regression analysis). Untuk menguji regresi dengan variabel moderating digunakan uji nilai selisih mutlak Frucot dan Shearon (1991) dalam Suhartini (2007) mengajukan model regresi yang agak berbeda untuk menguji pengaruh moderasi yaitu dengan model nilai selisih mutlak dari variabel independen. Pada uji nilai selisih mutlak, nilai setiap variabel bebas dengan variabel pemoderasi merupakan standardized score. Analisis dengan uji nilai selisih mutlak ini dilakukan dengan bantuan program SPPS 20 sehingga akan diperoleh nilai koefisien determinasi, nilai statistik $F$ dan nilai satistik $t$ yang digunakan pada penggunaan hipotesis. Dengan persamaan regresi berganda sebagai berikut:

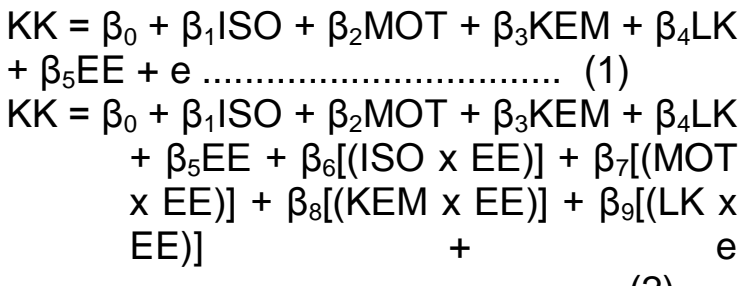

Keterangan:

\begin{tabular}{|c|c|}
\hline $\begin{array}{l}\text { KK } \\
\text { ISO } \\
\text { ISO } 9001 \cdot 2008\end{array}$ & $\begin{array}{l}\text { Kinerja Karyawan } \\
\text { Sistem Manajemen Mutu }\end{array}$ \\
\hline 10T & Motivasi Kerja \\
\hline 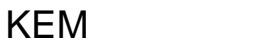 & Kemampuan Karyawan \\
\hline & Employee Engagement \\
\hline (ISO $x$ EE)] & $\begin{array}{l}\text { Lingkungan Kerja } \\
\text { Absolut interaksi ISO dan }\end{array}$ \\
\hline $\begin{array}{l}\text { МOT x EE)] } \\
\text { an EE }\end{array}$ & Absolut interaksi $\mathrm{MO}$ \\
\hline $\begin{array}{l}\text { (EM x EE)] } \\
\text { in EE }\end{array}$ & Absolut interaksi \\
\hline $\mathrm{K} \times \mathrm{EE})]$ & Absolut interaksi \\
\hline & $\operatorname{tar}$ \\
\hline
\end{tabular}

\section{$\beta_{1}-\beta_{5} \quad:$ Koefisien Regresi \\ e : Tingkat kesalahan \\ penduga dalam penelitian \\ Analisa Dan Pembahasan \\ Analisis Deskriptif Variabel Penelitian}

Deskriptif variabel penelitian dilakukan untuk mendapatkan gambaran mengenai jawaban responden dalam penelitian yang didasarkan pada nilai ratarata (mean) atas setiap jawaban responden pada masing-masing variabel penelitian. Skala penilaian menggunakan skala likert mulai dari angka 1 sampai dengan 5, dimana penentuan intervalnya dihitung dengan menggunakan rumus sebagai berikut:

$$
\begin{array}{ll}
\text { Interval } & \frac{\text { Nilai Terbesar }- \text { Nilai Terkecil }}{\text { Jumlah Kelas }} \\
\text { Interval } & \frac{\mathbf{5 - 1}}{\mathbf{5}}=
\end{array}
$$

Dari perhitungan rumus di atas, maka interval kelas yang diperoleh adalah 0,8. Dengan mengetahui bahwa jumlah kelas adalah 5 dan interval 0,8 sehingga kategori penilaiannya adalah sebagai berikut:

Tabel 1

Kategori Penilaian Variabel

\begin{tabular}{cc}
\hline Nilai Interval & Kategori \\
\hline $1,00 \leq-\geq 1,80$ & Sangat Rendah \\
$1,81 \leq-\geq 2,50$ & Rendah \\
$2,51 \leq-\geq 3,40$ & Cukup \\
$3,41 \leq-\geq 4,20$ & Tinggi \\
$4,21 \leq-\geq 5,00$ & Sangat Tinggi \\
\hline
\end{tabular}

\section{a. Sistem Manajemen Mutu ISO 9001: 2008}

Distribusi jawaban responden terhadap variabel sistem manajemen mutu ISO 9001: 2008 pada tabel 2 menunjukkan bahwa responden jawaban setiap indikator dengan kategori tinggi. 
Tabel 2

Kategori Variabel Sistem Manajemen Mutu ISO 9001: 2008

\begin{tabular}{|c|c|c|c|c|c|c|c|c|}
\hline \multirow{2}{*}{ No } & \multirow{2}{*}{ Indikator } & \multicolumn{5}{|c|}{ Skor Jawaban } & \multirow{2}{*}{ Mean } & \multirow{2}{*}{ Kategori } \\
\hline & & 1 & 2 & 3 & 4 & 5 & & \\
\hline 1. & ISO1 & 0 & 3 & 3 & 35 & 29 & 4,28 & Sangat Tinggi \\
\hline 2. & ISO2 & 1 & 2 & 8 & 39 & 20 & 4,07 & Tinggi \\
\hline 3. & ISO3 & 1 & 1 & 15 & 33 & 20 & 4,00 & Tinggi \\
\hline 4. & ISO4 & 1 & 2 & 5 & 47 & 15 & 4,04 & Tinggi \\
\hline 5. & ISO5 & 1 & 2 & 9 & 39 & 19 & 4,04 & Tinggi \\
\hline 6. & ISO6 & 2 & 2 & 1 & 41 & 24 & 4,18 & Tinggi \\
\hline 7. & ISO7 & 0 & 4 & 10 & 43 & 13 & 3,93 & Tinggi \\
\hline 8. & ISO8 & 1 & 5 & 20 & 32 & 12 & 3,70 & Tinggi \\
\hline 9. & ISO9 & 1 & 4 & 11 & 43 & 11 & 3,84 & Tinggi \\
\hline 10. & ISO10 & 1 & 2 & 6 & 47 & 14 & 4,01 & Tinggi \\
\hline 11. & ISO11 & 0 & 3 & 2 & 45 & 20 & 4,17 & Tinggi \\
\hline 12. & ISO12 & 0 & 4 & 11 & 44 & 11 & 3,88 & Tinggi \\
\hline 13. & ISO13 & 0 & 2 & 16 & 40 & 12 & 3,88 & Tinggi \\
\hline 14. & ISO14 & 0 & 4 & 19 & 41 & 6 & 3,70 & Tinggi \\
\hline 15. & ISO15 & 0 & 4 & 11 & 42 & 13 & 3,91 & Tinggi \\
\hline 16. & ISO16 & 0 & 3 & 11 & 46 & 10 & 3,90 & Tinggi \\
\hline 17. & ISO17 & 0 & 2 & 11 & 43 & 14 & 3,98 & Tinggi \\
\hline 18. & ISO18 & 0 & 3 & 18 & 38 & 11 & 3,81 & Tinggi \\
\hline 19. & ISO19 & 0 & 3 & 7 & 52 & 8 & 3,92 & Tinggi \\
\hline 20. & ISO20 & 0 & 3 & 12 & 46 & 9 & 3,87 & Tinggi \\
\hline 21. & ISO21 & 0 & 2 & 9 & 46 & 13 & 4,00 & Tinggi \\
\hline 22. & ISO22 & 0 & 6 & 23 & 36 & 5 & 3,57 & Tinggi \\
\hline \multirow[t]{2}{*}{23} & ISO23 & 0 & 4 & 32 & 30 & 4 & 3,48 & Tinggi \\
\hline & & Tota & & & & & 3,92 & Tinggi \\
\hline
\end{tabular}

b. Motivasi Kerja Karyawan

Distribusi jawaban responden terhadap variabel motivasi kerja karyawan pada tabel 3 menunjukkan bahwa responden jawaban setiap indikator dengan kategori tinggi.

Tabel 3

Kategori Variabel Motivasi Kerja Karyawan

\begin{tabular}{|c|c|c|c|c|c|c|c|c|}
\hline \multirow[b]{2}{*}{ No } & \multirow{2}{*}{ Indikator } & \multicolumn{5}{|c|}{ Skor Jawaban } & \multirow[b]{2}{*}{ Mean } & \multirow[b]{2}{*}{ Kategori } \\
\hline & & 1 & 2 & 3 & 4 & 5 & & \\
\hline 1. & MKK1 & 0 & 1 & 23 & 34 & 12 & 3,81 & Tinggi \\
\hline 2. & MKK2 & 0 & 0 & 17 & 29 & 24 & 4,10 & Tinggi \\
\hline 3. & MKK3 & 0 & 0 & 23 & 33 & 14 & 3,87 & Tinggi \\
\hline 4. & MKK4 & 0 & 0 & 23 & 31 & 16 & 3,90 & Tinggi \\
\hline
\end{tabular}




\begin{tabular}{ccccccccc} 
5. & MKK5 & 0 & 0 & 29 & 21 & 20 & 3,87 & Tinggi \\
6. & MKK6 & 1 & 1 & 31 & 34 & 3 & 3,53 & Tinggi \\
7. & MKK7 & 0 & 2 & 26 & 30 & 12 & 3,74 & Tingi \\
8. & MKK8 & 0 & 1 & 26 & 30 & 13 & 3,78 & Tinggi \\
9. & MKK9 & 0 & 0 & 32 & 28 & 10 & 3,68 & Tinggi \\
10. & MKK10 & 0 & 0 & 18 & 26 & 26 & 4,11 & Tinggi \\
11. & MKK11 & 0 & 0 & 24 & 37 & 9 & 3,78 & Tinggi \\
12. & MKK12 & 0 & 0 & 27 & 42 & 1 & 3,63 & Tingi \\
13. & MKK13 & 0 & 0 & 21 & 40 & 9 & 3,83 & Tinggi \\
14. & MKK14 & 1 & 0 & 26 & 33 & 10 & 3,73 & Tinggi \\
15. & MKK15 & 0 & 0 & 30 & 32 & 8 & 3,68 & Tinggi \\
16. & MKK16 & 0 & 0 & 27 & 29 & 14 & 3,81 & Tinggi \\
17. & MKK17 & 0 & 0 & 29 & 34 & 7 & 3,68 & Tinggi \\
\hline
\end{tabular}

c. Kemampuan Kerja Karyawan

Distribusi jawaban responden terhadap variabel kemampuan kerja dengan kategori tinggi.

Tabel 4

Kategori Variabel Kemampuan Kerja Karyawan

\begin{tabular}{|c|c|c|c|c|c|c|c|c|}
\hline \multirow{2}{*}{ No } & \multirow{2}{*}{ Indikator } & \multicolumn{5}{|c|}{ Skor Jawaban } & \multirow{2}{*}{ Mean } & \multirow{2}{*}{ Kategori } \\
\hline & & 1 & 2 & 3 & 4 & 5 & & \\
\hline 1. & KMP1 & 0 & 0 & 15 & 41 & 14 & 3,98 & Tinggi \\
\hline 2. & KMP2 & 0 & 0 & 10 & 35 & 25 & 4,21 & Sangat Tinggi \\
\hline 3. & KMP3 & 0 & 0 & 15 & 40 & 15 & 4,00 & Tinggi \\
\hline 4. & KMP4 & 0 & 0 & 17 & 38 & 15 & 3,97 & Tinggi \\
\hline 5. & KMP5 & 0 & 0 & 20 & 30 & 20 & 4,00 & Tinggi \\
\hline 6. & KMP6 & 0 & 0 & 23 & 44 & 3 & 3,71 & Tinggi \\
\hline 7. & KMP7 & 0 & 0 & 19 & 41 & 10 & 3,87 & Tinggi \\
\hline 8. & KMP8 & 0 & 0 & 17 & 41 & 12 & 3,93 & Tinggi \\
\hline 9. & KMP9 & 0 & 0 & 20 & 42 & 8 & 3,83 & Tinggi \\
\hline \multicolumn{7}{|c|}{ Total } & 3,94 & Tinggi \\
\hline
\end{tabular}

d. Lingkungan Kerja

Distribusi jawaban responden terhadap variabel lingkungan kerja pada tabel 5 menunjukkan bahwa responden jawaban setiap indikator dengan kategori tinggi.

Tabel 5

Kategori Variabel Lingkungan Kerja

\begin{tabular}{|c|c|c|c|c|c|c|c|c|}
\hline \multirow{2}{*}{ No } & \multirow{2}{*}{ Indikator } & \multicolumn{5}{|c|}{ Skor Jawaban } & \multirow{2}{*}{ Mean } & \multirow{2}{*}{ Kategor } \\
\hline & & 1 & 2 & 3 & 4 & 5 & & \\
\hline 1. & LK1 & 21 & 24 & 11 & 11 & 3 & 2,30 & Rendah \\
\hline 2. & LK2 & 1 & 5 & 13 & 35 & 16 & 3,86 & Tinggi \\
\hline 3. & LK3 & 0 & 5 & 24 & 36 & 5 & 3,58 & Tinggi \\
\hline 4. & LK4 & 1 & 3 & 12 & 41 & 13 & 3,88 & Tinggi \\
\hline 5. & LK5 & 27 & 23 & 5 & 12 & 3 & 2,16 & Rendah \\
\hline 6. & LK6 & 5 & 4 & 12 & 33 & 16 & 3,73 & Tinggi \\
\hline 7. & LK7 & 5 & 4 & 9 & 37 & 15 & 3,76 & Tinggi \\
\hline 8. & LK8 & 1 & 5 & 16 & 34 & 14 & 3,78 & Tinggi \\
\hline 9. & LK9 & 0 & 4 & 11 & 50 & 5 & 3,80 & Tinggi \\
\hline 10. & LK10 & 0 & 4 & 16 & 40 & 10 & 3,80 & Tinggi \\
\hline 11. & LK11 & 2 & 2 & 10 & 40 & 16 & 3,94 & Tinggi \\
\hline 12. & LK12 & 2 & 3 & 3 & 44 & 18 & 4,04 & Tinggi \\
\hline \multicolumn{7}{|c|}{ Total } & 3,55 & Tinggi \\
\hline
\end{tabular}


pada tabel 6 menunjukkan bahwa

dengan kategori tinggi.

responden jawaban setiap indikator

Tabel 6

Kategori Variabel Employee Engagement

\begin{tabular}{|c|c|c|c|c|c|c|c|c|}
\hline \multirow{2}{*}{ No } & \multirow{2}{*}{ Indikator } & \multicolumn{5}{|c|}{ Skor Jawaban } & \multirow{2}{*}{ Mean } & \multirow[b]{2}{*}{ Kategor } \\
\hline & & 1 & 2 & 3 & 4 & 5 & & \\
\hline 1. & EE1 & 0 & 5 & 27 & 26 & 12 & 3,64 & Tinggi \\
\hline 2. & EE2 & 0 & 5 & 17 & 24 & 24 & 3,96 & Tinggi \\
\hline 3. & EE3 & 1 & 11 & 23 & 21 & 14 & 3,51 & Tinggi \\
\hline 4. & EE4 & 0 & 8 & 23 & 23 & 16 & 3,67 & Tinggi \\
\hline 5. & EE5 & 0 & 5 & 29 & 16 & 20 & 3,73 & Tinggi \\
\hline 6. & EE6 & 8 & 17 & 30 & 12 & 3 & 2,78 & Cukup \\
\hline 7. & EE7 & 0 & 14 & 26 & 18 & 12 & 3,40 & Cukup \\
\hline 8. & EE8 & 0 & 14 & 24 & 20 & 12 & 3,43 & Tinggi \\
\hline 9. & EE9 & 1 & 10 & 31 & 19 & 9 & 3,36 & Cukup \\
\hline 10. & EE10 & 0 & 3 & 18 & 23 & 26 & 4,03 & Tinggi \\
\hline 11. & EE11 & 0 & 18 & 25 & 16 & 9 & 3,17 & Cukup \\
\hline 12. & EE12 & 2 & 19 & 33 & 15 & 1 & 2,91 & Cukup \\
\hline 13. & EE13 & 1 & 12 & 29 & 19 & 9 & 3,33 & Cukup \\
\hline 14. & EE14 & 4 & 14 & 25 & 18 & 9 & 3,20 & Cukup \\
\hline 15. & EE15 & 0 & 8 & 30 & 24 & 8 & 3,46 & Tinggi \\
\hline 16. & EE16 & 1 & 10 & 27 & 18 & 14 & 3,48 & Tinggi \\
\hline 17. & EE17 & 0 & 7 & 29 & 27 & 7 & 3,48 & Tinggi \\
\hline \multicolumn{7}{|c|}{ Total } & 3,44 & Tinggi \\
\hline
\end{tabular}

\section{f. Kinerja Karyawan}

Distribusi jawaban responden tabel 7 menunjukkan bahwa responden jawaban setiap indikator dengan kategori tinggi.

terhadap variabel kinerja karyawan pada

Tabel 7

Kategori Variabel Kinerja Karyawan

\begin{tabular}{|c|c|c|c|c|c|c|c|c|}
\hline \multirow{2}{*}{ No } & \multirow{2}{*}{ Indikator } & \multicolumn{5}{|c|}{ Skor Jawaban } & \multirow[b]{2}{*}{ Mean } & \multirow[b]{2}{*}{ Kategori } \\
\hline & & 1 & 2 & 3 & 4 & 5 & & \\
\hline 1. & KK1 & 1 & 3 & 3 & 52 & 11 & 3,98 & Tinggi \\
\hline 2. & KK2 & 1 & 3 & 7 & 48 & 11 & 3,93 & Tinggi \\
\hline 3. & KK3 & 1 & 3 & 11 & 48 & 7 & 3,81 & Tinggi \\
\hline 4. & KK4 & 1 & 2 & 9 & 48 & 10 & 3,91 & Tinggi \\
\hline 5. & KK5 & 1 & 2 & 4 & 52 & 11 & 4,00 & Tinggi \\
\hline 6. & KK6 & 1 & 2 & 4 & 52 & 11 & 4,00 & Tinggi \\
\hline 7. & KK7 & 1 & 3 & 5 & 47 & 14 & 4,00 & Tinggi \\
\hline 8. & KK8 & 0 & 3 & 2 & 45 & 20 & 4,17 & Tinggi \\
\hline 9. & KK9 & 0 & 3 & 3 & 45 & 19 & 4,14 & Tinggi \\
\hline 10. & KK10 & 0 & 3 & 6 & 45 & 16 & 4,06 & Tinggi \\
\hline & & Tota & & & & & 4,00 & Tinggi \\
\hline
\end{tabular}




\section{Uji Asumsi Klasik}

Tujuan dari uji asumsi klasik adalah untuk mengetahui bahwa regresi linear terbebas dari masalah-masalah normalitas dan multikolinearitas. Artinya asumsiasumsi linear untuk menghindari munculnya bias dalam analisis data serta menghindari kesalahan spesifiksi model regresi yang digunakan. Berikut hasil uji asumsi klasik variabel independen yang diteliti.

\section{Uji Normalitas}

Dengan tujuan untuk mengetahui apakah residual data dari model regresi linear memiliki distribusi normal ataukah tidak. Pengujian normalitas data pada penelitian ini dilakukan dengan menggunakan One-Sample KolmogorovSmirnov test. Ketentuan untuk menentukan distribusi normal data yaitu:

a. Bila nilai signifikan $\geq \alpha(5 \%)$, maka HO diterima, artinya data berdistribusi normal.

b. Bila nilai siginifikan $<\alpha(5 \%)$, maka $\mathrm{H} 1$ diterima, artinya data tidak berdistribusi normal.

Berikut hasil uji One-Sample Kolmogorov-Smirnov test seperti tabel 8 berikut:

Tabel 8

One-Sample Kolmogorov-Smirnov Test

\begin{tabular}{llr}
\hline & & Unstandardized Residual \\
\hline $\mathrm{N}$ & & 70 \\
Normal Parameters & Mean & $0 \mathrm{E}-7$ \\
& Std. Deviation &, 51615795 \\
Most Extreme & Absolute & 181 \\
Differences & Positive &, 151 \\
Kolmogorov-Smirnov Z & Negative &,- 181 \\
Asymp. Sig. (2-tailed) & & 1,152 \\
a. Test distribution is Normal. &, 220 \\
b. Calculated from data. & \\
&
\end{tabular}

\section{Sumber: Diolah dari hasil analisis}

Berdasarkan hasil uji One-Sample Kolmogorov-Smirnov test seperti terlihat pada tabel 4.18, menunjukkan bahwa nilai asympt. Sig (2-tailed) sebesar 0,220. Karena nilai $0,220>\alpha(0,05)$, maka dapat disimpulkan bahwa data berdistribusi normal. Artinya semua variabel independen yang diteliti mempunyai data yang berdistribusi normal.

\section{Uji Multikolinearitas}

Uji ini digunakan untuk menguji apakah ada atau tidak korelasi antara variabel indepdenden dalam model regresi, artinya ada hubungan linear antar variabel independen dalam model regresi. Yang mana biila terjadi korelasi antar variabel independen, maka model regresi menjadi bias. Dengan ketentuan model regresi yang baik, seharusnya tidak terjadi korelasi antara variabel bebasnya. Nilai cut off yang umumnya dipakai untuk menunjukkan bahwa semua variabel bebas tidak mempunyai masalah multikolinearitas adalah nilai tolerance > 0,10 atau nilai $\mathrm{VIF}<10$. Berikut hasil uji multikolinieritas, seperti pada tabel 9:

Tabel 9

Uji Multikolinearitas

\begin{tabular}{lcc}
\hline \multirow{2}{*}{ Variabel Independen } & \multicolumn{2}{c}{ Nilai Collinearity Statistics } \\
\cline { 2 - 3 } & Tolerance & VIF \\
\hline ISO & 0,750 & 1,333 \\
MKK & 0,394 & 2,537
\end{tabular}




\begin{tabular}{lll} 
KMP & 0,427 & 2,342 \\
LK & 0,813 & 1,230 \\
EE & 0,563 & 1,777 \\
\hline
\end{tabular}

Sumber: Diolah dari hasil analisis

Berdasarkan hasil uji multikolinearitas sperti pada tabel 4.19 diatas, mennjukkan bahwa nilai tolerance semua variabel tersebut $>0,10$. Selanjuntnya untuk nilai VIF variabel pengendalian waktu sebesar 1,478, dan nilai VIF semua variabel $<10$. Sehingga dapat disimpulkan bahwa variabel yang diteliti tidak mengandung multikolinearitas.

\section{Pengujian Hipotesis}

Tujuan dari uji hipotesis ini adalah untuk membuktikan apakah hipotesis yang diajukan terbukti atau tidak terbukti. Pembuktian hipotesis ini menggunakan 2 (dua) model regresi yaitu regresi linier berganda dan moderating regression analisys (MRA). Berikut hasil uji kedua model tersebut, seperti tabel 10:

Tabel 10

Hasil Uji Model Regresi

\begin{tabular}{|c|c|c|c|}
\hline Variabel & Koefisien regresi & T hitung & Signifikan \\
\hline \multicolumn{4}{|c|}{ Persamaan Regresi Model 1} \\
\hline (constant) & 1,155 & & \\
\hline ISO & 0,560 & 4,688 & 0,000 \\
\hline MKK & 0,264 & 2,640 & 0,012 \\
\hline KMP & 0,036 & 2,199 & 0,028 \\
\hline LK & 0,281 & 2,410 & 0,019 \\
\hline $\mathrm{EE}$ & 0,056 & 1,905 & 0,046 \\
\hline $\mathrm{R}$ & 0,688 & & \\
\hline R Square & 0,473 & & \\
\hline Adjusted R Square & 0,432 & & \\
\hline F hitung & 11,481 & & \\
\hline Signifikan $\mathrm{F}$ hitung & 0,000 & & \\
\hline N & 70 & & \\
\hline \multicolumn{4}{|c|}{ Persamaan Regresi Model 2} \\
\hline (constant) & 1,208 & & \\
\hline ISO & 0,202 & ,937 & 0,353 \\
\hline MKK & 0,533 & 253 & 0,279 \\
\hline KMP & 0,041 & ,165 & 0,869 \\
\hline LK & 0,006 & 037 & 0,970 \\
\hline EE & 0,499 & 2,164 & 0,034 \\
\hline Interaksi ISO*EE & 0,088 & 2,999 & 0,004 \\
\hline Interaksi MKKEE & 0,108 & 2,225 & 0,023 \\
\hline Interaksi KMP*EE & 0,002 & 1,903 & 0,040 \\
\hline Interaksi LKEE & 0,171 & 2,630 & 0,011 \\
\hline $\mathrm{R}$ & 0,756 & & \\
\hline R Square & 0,571 & & \\
\hline Adjusted R Square & 0,507 & & \\
\hline$F$ hitung & 8,890 & & \\
\hline Signifikan F hitung & 0,000 & & \\
\hline N & 70 & & \\
\hline
\end{tabular}

Sumber: Diolah dari hasil analisis

Berdasarkan hasil uji regresi tersebut, maka model regresi berganda dan model regresi moderating dapat disusun sebagai berikut:

\section{Model Regresi Berganda}

$\mathrm{KK}=\alpha+\beta_{1}$ ISO $+\beta_{2} \mathrm{MKK}+\beta_{3} \mathrm{KMP}$

$+\beta_{4} \mathrm{LK}+\beta_{5} \mathrm{EE}+\varepsilon_{1}$

$\mathrm{KK}=1,155+0,560 \mathrm{ISO}+0,264$

$\mathrm{MKK}+0,036 \mathrm{KMP}+0,281 \mathrm{LK}+0,056 \mathrm{EE}$

Model regresi diatas menunjukkan bahwa nilai koefisien regresinya bernilai positif artinya mempunyai hubungan yang searah, Karena nilai koefisien regresinya bernilai positif. Hal ini menunjukkan bahwa bila koefisien regresi dari masing-masing 
variabel independen naik satu-satuan, maka variabel kinerja karyawan akan naik satu-satuan sebesar nilai koefisien regesi dari masing-masing dari independen tersebut. Begitu sebaliknya bila nilai koefisien regresi dari masing-masing variabel independen turun satu-satuan, maka nilai dari variabel kinerja proyek akan turun satu-satuan sebesar nilai koefisen regresi variabel independen.

\section{Model Regresi Moderating}

$$
\begin{aligned}
& \mathrm{KK}=\alpha+\beta_{1} \text { ISO }+\beta_{2} \mathrm{MKK}+\beta_{3} \mathrm{KMP} \\
& +\beta_{4} \mathrm{LK}+\beta_{5} \mathrm{EE}+\beta_{6} \text { ISO*EE }+\beta_{7} \\
& \mathrm{MKK}^{*} \mathrm{EE}+\beta_{8} \mathrm{KMP}^{*} \mathrm{EE}+\beta_{9} \\
& \mathrm{LK}^{\star} \mathrm{EE}+\varepsilon_{2} \\
& =1,208+0,202 \text { ISO }+0,533 \\
& \mathrm{MKK}+0,041 \quad \mathrm{KMP}+0,006 \\
& \mathrm{LK}+0,499 \mathrm{EE}+0,088 \mathrm{ISO} * \mathrm{EE}+ \\
& 0,108 \mathrm{MKK}^{\star} \mathrm{EE}+0,002 \mathrm{KMP}^{\star} \mathrm{EE} \\
& +0,171 \mathrm{LK}^{\star} \mathrm{EE}
\end{aligned}
$$

Model regresi diatas menunjukkan bahwa hubungan yang positif. Ini berarti nilai koefisien regresi variabel independen dan hasil interaksi yang bernilai positif mempunyai hubungan yang searah dengan variabel kinerja karyawan,

\section{Pembahasan}

\subsubsection{Pengaruh Sistem Manajemen}

Mutu ISO 9001: 2008 terhadap Kinerja Karyawan Puskesmas di Surabaya

Dari hasil pengujian hipotesis 1 menunjukkan bahwa sistem manajemen mutu ISO 9001: 2008 berpengaruh secara signifikan terhadap kinerja karyawan puskesmas di Surabaya. Hal ini menunjukkan bahwa dengan adanya penerapan sistem manajemen mutu ISO 9001: 2008 dapat mendorong karyawan untuk mematuhi sistem manajemen mutu yang telah ditetapkan oleh puskesmas, yang kemudian akan meningkatkan kinerja karyawan.

Standar internasional untuk sistem manajemen mutu yang menetapkan persyaratan-persyaratan dan rekomendai untuk penilaian dari suatu manajemen mutu sudah berjalan dengan baik pada puskesmas di Surabaya. Semuel dan Zulkarnain (2011) menyatakan bahwa penerapan sistem manajemen mutu ISO
9001 yang meliputi perencanaan sertifikasi, komitmen organisasi, dan penerapan prosedur, memiliki persepsi yang beragam dari karyawan responden, dimana perencanaan sertifikasi memiliki persepsi yang sangat baik dibandingkan dengan dua variabel lainnya. Penerapan sistem manajemen mutu ISO 9001 mampu meningkatkan kinerja karyawan secara signifikan melalui budaya kualitas perusahaan sebagai mediasinya (Semuel dan Zulkarnain, 2011).

Fahat (2016) menganalisis pengaruh sistem manajemen mutu ISO terhadap kinerja karyawan melalui budaya kualitas organisasi pada puskesmas di Yogyakarta. Perencanaan sertifikasi ISO 9001, komitmen perusahaan, dan penerapan prosedur dipersepsikan sudah sangat baik oleh karyawan dan berpengaruh positif secara signifikan terhadap kinerja karyawan melalui budaya kualitas.

Dari hasil pengujian hipotesis 2 menunjukkan bahwa employee engagement mampu memoderasi pengaruh sistem manajemen mutu ISO 9001: 2008 terhadap kinerja karyawan puskesmas di Surabaya. Peran serta karyawan dan antusiasme karyawan untuk bekerja dengan rasa keterikatan emosional yang positif dan komitmen karyawan, ditunjang dengan puskesmas memiliki standar sistem operasional yang jelas, dan puskesmas sudah memiliki kebijakan mutu, sasaran mutu, dan strategi dalam mencapai sasaran mutu dengan jelas akan dapat meningkatkan kinerja karyawan.

Margaretha dan Santosa (2012), ketika para karyawan memiliki persepsi yang tinggi tentang keadilan dalam organisasi mereka, dipastikan mereka merasa diwajibkan atau diharuskan untuk berlaku adil dalam memainkan peran mereka dengan memberi lebih besar melebihi tingkat engagement.

\subsubsection{Pengaruh Motivasi dan Kemampuan Kerja terhadap Kinerja Karyawan Puskesmas di Surabaya}

Dari hasil pengujian hipotesis 3 menunjukkan bahwa motivasi kerja dan kemampuan kerja berpengaruh secara 
signifikan terhadap kinerja karyawan puskesmas di Surabaya. Ketika karyawan mempunyai motivasi yang tinggi untuk meningkatkan kualitas pelayanan, maka akan dapat meningkatkan kinerja karyawan. Selain itu, kemampuan yang tinggi dalam melaksanakan pekerjaan yang dibebankan akan meningkatkan kinerja karyawan. Sehingga seleksi karyawan sesuai dengan kemampuan bidangnya sangat dibutuhkan, karena kemampuan yang sesuai dengan bidangnya akan meningkatkan kinerja. Dan sebaliknya, karyawan yang memiliki kemampuan namun tidak sesuai dengan bidang pekerjaannya, kinerjanya akan menurun.

Sutrischastini dan Riyanto (2015), motivasi terbentuk dari sikap (attitude) dalam menghadapi situasi kerja (situation) merupakan energi yang menggerakkan diri mereka yang bertujuan mencapai tujuan organisasi. Sutrischastini dan Riyanto (2015) menyimpulkan bahwa terdapat hubungan yang positif dan signifikan antara motivasi kerja dengan tingkat kinerja. Para pegawai yang memiliki motivasi kerja tinggi akan cenderung memiliki tingkat kinerja yang tinggi, dan sebaliknya mereka yang kurang memiliki motivasi untuk berprestasi akan memperoleh kinerja yang rendah.

Setiawan (2015) menyatakan terdapat pengaruh positif secara langsung motivasi kerja terhadap kinerja pada karyawan dengan nilai koefisien jalur sebesar 0,157. Pengaruh tersebut menunjukkan bahwa karyawan level pelaksana memiliki motivasi tinggi yang akan selalu mencoba melakukan yang terbaik serta bersedia meluangkan waktu dan upaya ekstra untuk melakukan pekerjaannya sehingga akan meningkatkan kinerjanya.

Permatasari et al. (2016), semakin baik kemampuan yang dimiliki karyawan maka kinerja yang dihasilkan karyawan juga semakin baik. Arini et al. (2015), karyawan yang tanggap dalam mengerjakan pekerjaan yang dibebankannya, maka kinerja yang dihasilkan sesuai dengan standar perusahaan. Selain itu, motivasi yang diberikan oleh rekan kerja juga dapat meningkatkan kinerja yang dihasilkan.

$$
\text { Kemampuan dan motivasi }
$$

berpengaruh secara bersama-sama terhadap kinerja pegawai sebesar $86 \%$ dan secara parsial diketahui bahwa pengaruh motivasi lebih dominan daripada pengaruh kemampuan (Anggraeni, 2011).

Dari hasil pengujian hipotesis 4 menunjukkan bahwa employee engagement mampu memoderasi pengaruh motivasi kerja dan kemampuan karyawan terhadap kinerja karyawan puskesmas di Surabaya. Engagement dilakukan bagaimana individu mempekerjakan diri mereka sendiri untuk mencapai kinerja dalam pekerjaannya, selain itu engagement melibatkan emosi dan perilaku secara aktif juga melibatkan aspek kognitif (Margaretha dan Santosa, 2012).

\subsubsection{Pengaruh Employee Engangement terhadap Kinerja Karyawan Puskesmas di Surabaya}

Dari hasil pengujian hipotesis 5 menunjukkan bahwa employee engagement berpengaruh secara signifikan terhadap kinerja karyawan puskesmas di Surabaya. Hal ini dapat diartikan bahwa employee engagement karyawan puskesmas sudah memberikan peranan penting serta antusiasme untuk bekerja. Employee engagement yang memiliki rasa keterikatan emosional yang positif dan komitmen karyawan akan dapat meningkatkan kinerja karyawan.

Kusmalinda et al. menyatakan bahwa employee engagement dapat digunakan untuk memprediksi peningkatan produktivitas karyawan dan profitabilitas, mempertahankan karyawan dan kepuasan konsumen serta keberhasilan organisasi. Kusmalinda et al. (2014) menyebutkan hal ini disebabkan karena karyawan yang memiliki tingkat engagement yang tinggi akan memiliki keterikatan emosi yang tinggi yang mempengaruhi karyawan dalam menyelesaikan pekerjaan (cenderung memiliki kualitas kerja yang memuaskan) yang akan berdampak pada peningkatan kinerja karyawan. 


\subsubsection{Pengaruh Lingkungan Kerja terhadap Kinerja Karyawan Puskesmas di Surabaya}

Dari hasil pengujian hipotesis 6 menunjukkan bahwa lingkungan kerja berpengaruh secara signifikan terhadap kinerja karyawan puskesmas di Surabaya. Hal ini dapat diartikan bahwa ruangan kerja dan fasilitas penunjang para pekerja dapat mempengaruhi karyawan dalam menjalankan tugas yang dibebankan. Lingkungan kerja yang kondusif diharapkan mampu memacu kinerja karyawan. Karyawan dituntut untuk melaksanakan pekerjaan sesuai dengan jabatan yang dipegang dan dapat berinteraksi dengan lingkungan serta rekan kerja yang memiliki karakter yang berbeda-beda akan dapat meningkatkan kinerja karyawan.

Subagiarta (2016) menyatakan bahwa lingkungan kerja berpengaruh positif dan signifikan terhadap kinerja pegawai. Kinerja di dalam perusahaan tergolong tinggi yang diukur dari kuantitas, kualitas, dan ketepatan waktu karena adanya faktor lingkungan kerja fisik dan non fisik yang mempengaruhi (Ningrum et al., 2014).

Dari hasil pengujian hipotesis 7 menunjukkan bahwa employee engagement mampu memoderasi lingkungan kerja terhadap kinerja karyawan puskesmas di Surabaya. Artinya peran serta karyawan dan antusiasme karyawan untuk bekerja dengan rasa keterikatan emosional yang positif dan komitmen karyawan, ditunjang dengan lingkungan kerja yang baik dan kondisi lingkungan kerja yang nyaman akan mempengaruhi karyawan bekerja lebih giat dan konsentrasi menyelesaikan tugastugasnya sesuai jadwal yang telah diberikan, sehingga akan meningkatkan kinerja karyawan yang bersangkutan.

Menurut Colquit et al. dalam Saks (2006), menjelaskan beberapa kondisi lingkungan kerja yang baik yang diharapkan dapat menciptakan employee engagement. Lingkungan kerja yang diharapkan berkeadilan akan membangun ikatan emosi yang lebih baik pada organisasi. Didalam lingkungan kerja yang baik akan memberikan kenyamanan pribadi dan dapat membangkitkan semangat kerja karyawan sehingga dapat mengerjakan tugas-tugasnya dengan baik.

\section{SIMPULAN DAN REKOMENDASI Simpulan}

Berdasarkan pembahasan terhadap hipotesis yang dirumuskan dalam penelitian ini, maka dapat disimpulkan sebagai berikut:

1. Sistem manajemen mutu ISO 9001: 2008 berpengaruh secara signifikan terhadap kinerja karyawan puskesmas di Surabaya. Hal ini menunjukkan bahwa dengan adanya penerapan sistem manajemen mutu ISO 9001: 2008 dapat mendorong karyawan untuk mematuhi sistem manajemen mutu yang telah ditetapkan oleh puskesmas, yang kemudian akan meningkatkan kinerja karyawan.

2. Employee engagement mampu memoderasi pengaruh sistem manajemen mutu ISO 9001: 2008 terhadap kinerja karyawan puskesmas di Surabaya. Peran serta karyawan dan antusiasme karyawan untuk bekerja dengan rasa keterikatan emosional yang positif dan komitmen karyawan, ditunjang dengan puskesmas memiliki standar sistem operasional yang jelas, dan puskesmas sudah memiliki kebijakan mutu, sasaran mutu, dan strategi dalam mencapai sasaran mutu dengan jelas akan dapat meningkatkan kinerja karyawan.

3. Motivasi kerja dan kemampuan kerja berpengaruh secara signifikan terhadap kinerja karyawan puskesmas di Surabaya. Ketika karyawan mempunyai motivasi yang tinggi untuk meningkatkan kualitas pelayanan, maka akan dapat meningkatkan kinerja karyawan. Selain itu, kemampuan yang tinggi dalam melaksanakan pekerjaan yang dibebankan akan meningkatkan kinerja karyawan. Sehingga seleksi karyawan sesuai dengan kemampuan bidangnya sangat dibutuhkan, karena kemampuan yang sesuai dengan bidangnya akan meningkatkan kinerja.

4. Employee engagement mampu memoderasi pengaruh motivasi kerja dan kemampuan karyawan terhadap 
kinerja karyawan puskesmas di Surabaya. Engagement dilakukan ketika individu mampu mempekerjakan diri mereka sendiri untuk mencapai kinerja dalam pekerjaannya.

5. Employee engagement berpengaruh secara signifikan terhadap kinerja karyawan puskesmas di Surabaya. Hal ini dapat diartikan bahwa employee engagement karyawan puskesmas sudah memberikan peranan penting serta antusiasme untuk bekerja. Employee engagement yang memiliki rasa keterikatan emosional yang positif dan komitmen karyawan akan dapat meningkatkan kinerja karyawan.

6. Lingkungan kerja berpengaruh secara signifikan terhadap kinerja karyawan puskesmas di Surabaya. Hal ini dapat diartikan bahwa ruangan kerja dan fasilitas penunjang para pekerja dapat mempengaruhi karyawan dalam menjalankan tugas yang dibebankan. Lingkungan kerja yang kondusif diharapkan mampu memacu kinerja karyawan.

7. Employee engagement mampu memoderasi lingkungan kerja terhadap kinerja karyawan puskesmas di Surabaya. Artinya peran serta karyawan dan antusiasme karyawan untuk bekerja dengan rasa keterikatan emosional yang positif dan komitmen karyawan, ditunjang dengan lingkungan kerja yang baik dan kondisi lingkungan kerja yang nyaman akan mempengaruhi karyawan bekerja lebih giat dan konsentrasi menyelesaikan tugas-tugasnya sesuai jadwal yang telah diberikan, sehingga akan meningkatkan kinerja karyawan yang bersangkutan.

\section{Rekomendasi}

Beberapa saran yang dapat dilakukan dalam penelitian selanjutnya adalah sebagai berikut:

1. Penelitian mendatang sebaiknya melakukan pilot test agar memudahkan responden memahami variabel yang diteliti.

2. Responden perlu diberitahu untuk tidak memberikan jawaban dari kuesioner yang diisi hanya berdasarkan persepsi mereka namun harus berdasarkan dengan kenyataan yang ada.

3. Sikap dan fungsi Employee Engagement perlu untuk disosialisasikan secara menyeluruh saat ini, karena employee engagment diperlukan untuk membangun suatu hubungan dan keterikatan antara karyawan dengan manajemen puncak sehingga dapat tercipta suatu organisasi yang berjalan sesuai dengan harapan yang diinginkan.

\section{DAFTAR PUSTAKA}

As'ad, M. 2003. Psikologi Industri. Libery. Yogyakarta.

Anggraeni, N. 2011. Pengaruh Kemampuan dan Motivasi terhadap Kinerja Pegawai pada Sekolah Tinggi Seni Indonesia (STSI) Bandung. Jurnal Penelitian Pendidikan 11(2): 54-74.

Antariksa, W. F., Surachman, dan M. Setiawan. $2014 . \quad$ Pengaruh Penerapan Sistem Manajemen Mutu ISO 9001: 2008 di Perguruan Tinggi terhadap Kinerja Balanced Scorecard (Studi Kasus pada Universitas Brawijaya). Jurnal Aplikasi Manajemen 12(3): 399-406.

Arini, K. R., M. D. Mukzam, dan I. Ruhana. 2015. Pengaruh Kemampuan Kerja dan Motivasi Kerja terhadap Kinerja Karyawan (Studi pada Karyawan PT. Perkebunan Nusantara X (Pabrik Gula) Djombang Baru). Jurnal Administrasi Bisnis (JAB) 22(1): 1-9.

Asikgil, B. dan Aydogdu. 2011. An Empirical Study of the Relationship among Job Satisfaction, Organizational Commitment and Turnover Intention. International Review of Management and Marketing 1(3): 43-53.

Cohen, G. 2007. Employee Engagement : The Secret of Highly Performing Organizations. Journal of Applied Human Capital Management Vol. 1 Number 2007.

Dernovsek, D. 2008. Creating Highly Engaged and Committed Employee Starts at the Top and Ends at the Bottom Line Credit Union Magazine. 
Credit Union National Association, Inc.

Djojowirono. 2005. Manajemen Konstruksi. Edisi Keempat. KMTS FT UGM. Yogyakarta.

Fahat, M. A. 2016. Pengaruh Sistem Manajemen Mutu ISO 9001: 2008 terhadap Kinerja Karyawan melalui Budaya Kualitas Perusahaan (Studi Kasus pada Puskesmas Mantrijeron Yogyakarta). Skripsi. Universitas Muhammadiyah Yogyakarta.

Hanafi, B. D. dan C. Yohana. 2017. Pengaruh Motivasi dan Lingkungan Kerja terhadap Kinerja Karyawan dengan Kepuasan Kerja sebagai Variabel Mediasi pada PT. BNI LIFEINSURANCE. Jurnal Pendidikan Ekonomi dan Bisnis (JPEB) 5(1): 7389.

Hernandez, H. 2010. Quality Audit as A Driver for Compliance to ISO 9001:2008 Standards. The TQM Journal 22(4): 454-466.

Kusmalinda, T., M. P. Putri, H. Setyoningrum, F. Arrahman, dan W.

A. Sagala. 2014. Pengaruh Employee Engagement terhadap Produktivitas Perusahaan. Mangkunegara, P. A. 2007. Manajemen Sumber Daya Manusia. Edisi Ketiga. Penerbit BPFE. Yogyakarta.

Moynihan, L. M., W. R. Boswell, dan J. R. Boudreau. 2000. The Influence of Job Satisfaction and Organizational Commitment on Executive withdrawal and Performance. Working Paper Series Center for Advanced Human Resource Studies (CAHRS). Cornell University ILR Study.

Ningrum, N. L., A. Prasetya, dan M. F. Riza. 2014. Pengaruh Lingkungan Kerja terhadap Kinerja Karyawan (Studi pada Karyawan Auto 2000 Sukun Malang). Jurnal Administrasi Bisnis 11(1): 1-9.

Nitisemito, A. S. 2002. Manajemen Sumber Daya Manusia. Cetakan Sembilan. Edisi Ketiga. Ghalia Indonesia. Jakarta.

Permatasari, R. D., B. Swasto, dan M. lqbal. 2016. Pengaruh Kemampuan
Kerja dan Komitmen Organisasional terhadap Kinerja Karyawan (Studi pada Karyawan Perusahaan Daerah Air Minum Kota Malang). Jurnal Administrasi Bisnis (JAB) 33(1): 5260.

Rahmayanti. 2014. Pengaruh Motivasi Kerja terhadap Kinerja Karyawan pada CV. Putra Kaltim Samarinda. Ejournal IImu Administrasi Bisnis 2(2): 215-229.

Robbins, S. P. dan T. A. Judge. 2015. Perilaku Organisasi. Salemba Empat. Jakarta.

Robinson, D., Perryman S., dan Hayday S. 2004. The Drivers of Employee Engagement Report 408. Institute for Employment Studies. UK.

Saks, A. M. 2006. The Antacendents and Consequence of Employee Engagement. Journal of Managerial Psychology 21(7): 600-619.

Samad, S. 2011. The Effects of Job Satisfactionon Organizational Commitment and Job Performance Relationship: a Case of Managers in Malaysia's Manufacturing Companies. European Journal of Social Sciences 18(4): 602-611.

Schultz, D. dan S. E. Schultz. 2015. Psychology and Work Today 10E. Routledge.

Sekaran, U. 2006. Research Methods for Business : A Skill Building Approach. 2nd Edition. John Wiley and Son. New York.

Semuel, H. dan J. Zulkarnain. 2011. Pengaruh Sistem Manajemen Mutu ISO terhadap Kinerja Karyawan melalui Budaya Kualitas Perusahaan (Studi Kasus PT. Otsuka Indonesia Malang). Jurnal Manajemen dan Kewirausahaan 13(2): 162-176.

Setiawan, K. C. 2015. Pengaruh Motivasi Kerja terhadap Kinerja Karyawan Level Pelaksana di Divisi Operasi PT. Pusri Palembang. PSIKIS-Jurnal Psikologi Islami 1(2): 43-53.

Sidanti, H. 2015. Pengaruh Lingkungan Kerja, Disiplin Kerja dan Motivasi Kerja terhadap Kinerja Pegawai Negeri Sipil di Sekretariat DPRD Kabupaten Madiun. Jurnal JIBEKA 9(1): 44-53. 
Stoner, JAF. 2000. Manajemen. Edisi Bahasa Indonesia. Prenhallindo. Jakarta.

Subagiarta, I. W. 2016. Pengaruh Lingkungan Kerja, Karakteristik Individu terhadap Kinerja Karyawan dengan Kesehatan Kerja sebagai Variabel Intervening (Studi pada Badan Pelayanan Perijinan Terpadu Satu Pintu dan Penanaman Modal Kota Denpasar). Jurnal Manajemen dan Bisnis 13(3): 159-167.

Suhartini, D. 2007. Pengaruh Penerapan Total Quality Management terhadap Kinerja Manajerial dengan Budaya Organisasi sebagai Variabel Moderating pada PT.Pertamina
(Persero) UPMS V Surabaya. Jurnal Ekonomi dan Manajemen 8(2).

Sutrischastini, A. dan A. Riyanto. 2015. Pengaruh Motivasi Kerja terhadap Kinerja Pegawai Kantor Sekretariat Daerah Kabupaten Gunung Kidul. Jurnal Kajian Bisnis 23(2): 121-137.

The Gallup Organization. 2004. www.gallup.com.

Warsi, S., N. Fatima, dan S. A. Sahibzada. 2009. Study on Relationship between Organizational Commitment and its Determinants among Private Sector Employee of Pakistan. International Review of Business Research Papers 5(3): 399- 410. 